Necessity and Opportunity Entrepreneurs and their Duration in Self-employment:

\title{
Evidence from German Micro Data
}

Jörn Block, Philipp Sandner

Discussion Paper 2007-10

October 2007

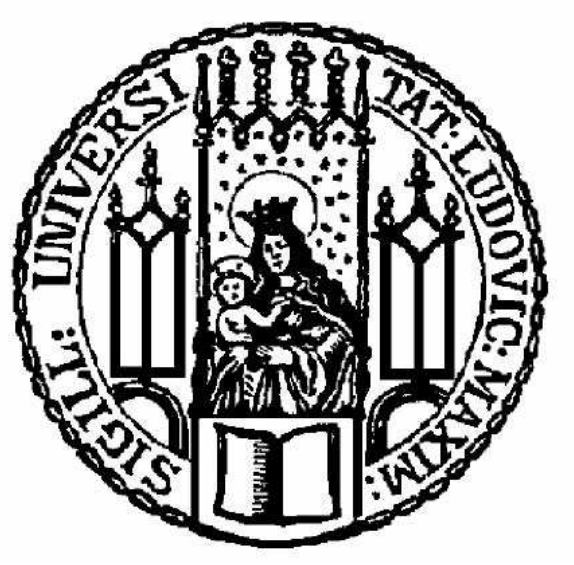

LMU

LUdWIG-MAXIMILIANS-UNIVERSITÄT MÜNCHEN

MUNICH SCHOOL OF MANAGEMENT

Online at http://epub.ub.uni-muenchen.de/ 


\title{
Necessity and Opportunity Entrepreneurs and their Duration in Self-employment: Evidence from German Micro Data
}

\author{
Jörn Block ${ }^{1}$, Philipp Sandner ${ }^{2}$ *
}

\begin{abstract}
Using data from the German Socio-Economic Panel Study (GSOEP), we analyze whether necessity entrepreneurs differ from opportunity entrepreneurs in terms of self-employment duration. Using univariate statistics, we find that opportunity entrepreneurs remain in selfemployment longer than necessity entrepreneurs. However, after controlling for the entrepreneurs' education in the professional area where they start their venture, this effect is no longer significant. We therefore conclude that the difference observed is not an original effect but rather is due to selection. We then go on to discuss the implications of our findings for entrepreneurship-policy making, and give suggestions to improve governmental start-up programs.
\end{abstract}

Keywords: Self-employment; Firm survival; Necessity entrepreneurs; Opportunity entrepreneurs; Hazard rates, GSOEP

JEL classification: J23; J24; M13; C41

\footnotetext{
${ }^{1}$ Schöller Chair in Technology and Innovation Management, Technische Universität München, Arcisstr. 21, D80333 Munich, Germany. Phone: +49-89-289 25746, email: block@wi.tum.de.

${ }^{2}$ Institute for Innovation Research, Technology Management and Entrepreneurship, Munich School of Management, Kaulbachstraße 45, D-80539 Munich, Germany. Phone: +49-89-2180 5809, e-mail: psandner@ bwl.unimuenchen.de.

* We would like to thank Oliver Alexy, Hans-Jürgen Block, Dietmar Harhoff, George Saridakis, Nico Siegel, Andrew Smith, Julian Süß, Marcus Wagner, Marc Weiglein, Hagen Worch and the participants in the institute seminar at the Max-Planck-Institute of Economics Jena, the Schöller Chair in Technology and Innovation Management, the G-Forum 2006, and the workshop on "entrepreneurship, firm demography and industrial location" at WIFO for helpful comments and suggestions. All remaining errors are ours.
} 


\section{Necessity and Opportunity Entrepreneurs and their Duration in Self-employment: Evidence from German Micro Data}

\section{Introduction}

In many countries, economic policy aims to increase the number of new businesses, but this goal is problematic since many new businesses do not survive for very long. For example, in Germany, an industrialized country, only about $50 \%$ of newly established businesses survive longer than 5 years (Fritsch et al., 2006). From a policy perspective, it might therefore be interesting to know more about the determinants of the length of survival of newly established businesses. This is especially relevant given the fact that in many industrialized countries, the state actively promotes entrepreneurship as a way out of unemployment (for an overview, see Meager, 1996). In addition to providing insights from the policy perspective, this paper is also interesting from a financial investor's perspective. Financial investors, whether venture capitalists, banks or business angels, want to calculate the expected return on their investment, and business survival is an integral part of this calculation. Any new information about the determinants of business survival makes their calculation more accurate and helps to avoid systematic decision biases.

Apart from the general question about the determinants of business survival, this paper aims to provide new insights relating to the impact of necessity and opportunity entrepreneurship on business survival. Using German micro data, we analyze whether an individual who stepped into self-employment voluntarily (an opportunity entrepreneur) remains selfemployed substantially longer than an individual who started self-employment for necessity reasons (a necessity entrepreneur). This question is particularly relevant from a German policy perspective because necessity entrepreneurship has increased strongly over the last few years due to policy measures taken by the federal government (e.g., Bergmann and Sternberg, 2007; Wagner, 2005). 
To identify the determinants of duration in self-employment, we estimate several hazard rate models using a stepwise procedure. By employing a stepwise procedure, we aim to determine whether any observable differences between the two groups are due to selection. To further explore the validity of our results, we compare the characteristics of necessity and opportunity entrepreneurs using descriptive statistics and Probit regression models.

In line with our ex-ante beliefs, we find that opportunity entrepreneurs stay in selfemployment significantly longer than do necessity entrepreneurs. This effect, however, is due to selection, and is not an original effect. After controlling for whether the venture is started in a profession the entrepreneur has learnt, the hazard of leaving self-employment is no longer affected by the individual's status as a necessity entrepreneur. This result opens an interesting debate regarding the relative economic impacts of opportunity and necessity entrepreneurs. Necessity entrepreneurs are not necessarily less successful and therefore less desirable from an economic perspective, as has been suggested in some literature (e.g., Acs et al., 2005; Acs and Varga, 2005). Rather, the observation of differences between necessity and opportunity entrepreneurs is highly sensitive to the definition of success that is used. To some degree, our finding justifies governmental programs of start-up support that are designed for necessity entrepreneurs. The efficiency of these programs, however, can be further improved by including education and other variables in the decision of whether to support a given individual entrepreneur.

The remainder of this paper is organized into four sections. In Section 2, we discuss from a theoretical perspective the relative impacts of necessity and opportunity entrepreneurship on self-employment duration. Moreover, we provide a short literature review of the impact of other factors on staying in self-employment. Section 3 introduces the data, gives some descriptive statistics, and describes the econometric models that we use. The estimation results 
are reported in Section 4. Finally, Section 5 discusses implications from a policy perspective and gives ideas for further research.

\section{The Determinants of Survival in Self-employment}

\subsection{Necessity versus Opportunity Entrepreneurship}

Since 2001, the Global Entrepreneurship Monitor (GEM) has discussed two different types of entrepreneurship: necessity entrepreneurship and opportunity entrepreneurship (e.g., Block and Wagner, 2007; Reynolds et al., 2002; Sternberg et al., 2006). The difference between the two types depends on the motivation of an entrepreneur to start her venture. Opportunity entrepreneurs are those who start their businesses in order to pursue an opportunity, while necessity entrepreneurship is more requirement-based (e.g., Reynolds et al., 2005). The reason these two types of entrepreneurs should differ regarding duration in self-employment is an open question from a theoretical point of view. We present arguments from human capital theory, which suggests that opportunity entrepreneurs should stay longer in self-employment than necessity entrepreneurs. We then argue that this is in fact an open question. A stronger, more monetary-driven motivation of necessity entrepreneurs can lead either to longer or shorter survival times than those of opportunity entrepreneurs. In the final paragraph, we discuss selection issues.

Our argument for the reason that opportunity entrepreneurs might stay longer in selfemployment than necessity entrepreneurs is rooted in human capital theory (e.g., Becker, 1962, 1964; Schultz, 1961). Human capital theory maintains that a higher stock of knowledge provides individuals with a higher cognitive ability, which then leads to more productive and efficient activity. Hence, individuals with more knowledge or with a stock of knowledge of higher quality are better at perceiving and exploiting entrepreneurial opportunities than are entrepreneurs with less human capital (Davidson and Honig, 2003; Shane, 2000). Human 
capital, however, encompasses more than formal education; it also includes experience and practical learning (Becker, 1964; Davidson and Honig, 2003). Empirical studies have shown that labor market experience, management experience, and previous entrepreneurial experience all have a strong impact on entrepreneurial success (Gimeno et al., 1997; Robison and Sexton, 1994). We argue that opportunity entrepreneurs who start their venture voluntarily have more knowledge and/or knowledge of a higher quality than necessity entrepreneurs. Opportunity entrepreneurs are likely to have prepared more systematically for their entry into self-employment, and are likely to have invested more in the specific human capital necessary to succeed as a business owner. For example, it might be that they have planned their career in a way that allowed them to gain valuable industry experience. Further, they might have attended a business planning course before starting their venture. Ceteris paribus, the relative advantage of opportunity entrepreneurs in human capital endowment is an argument for a longer survival time relative to necessity entrepreneurs.

Extant literature suggests that non-monetary benefits play an important role in pursuing entrepreneurship. Given their qualifications, many entrepreneurs could earn more in a wageearning job (Hamilton, 2000). This finding is difficult to interpret within the labor economics theory of occupational choice (Becker, 1964; Siow, 1984). In fact, given that self-employment earnings are less certain than wages from paid employment, self-employed individuals should demand a risk premium and consequently earn more than paid employees (Kanbur, 1982). For many entrepreneurs, however, it seems to be that money is only part of what matters. They gain utility from greater autonomy, from broader skill utilization, and from the possibility of pursuing their own ideas (Benz, 2005; Benz and Frey, 2004; Hundley, 2001). There is empirical evidence that even after controlling for job and personal characteristics, self-employed individuals tend to be more satisfied with their jobs than paid employees (e.g., Blanchflower, 2000; Frey and Benz, 2003). Almost by definition, necessity entrepreneurs are unlikely to 
have started their venture for non-monetary reasons. Consequently, non-monetary returns of entrepreneurship should have a greater impact on opportunity entrepreneurs than on necessity entrepreneurs. Whether this translates into a shorter or a longer survival time is an open question. On the one hand, stronger non-monetary returns enable entrepreneurs to cope better with problems such as economic downturns or customer dissatisfaction. On the other hand, once these non-monetary returns go away (e.g., the entrepreneur finds herself less independent than she had originally assumed), the entrepreneur might be more willing to quit her business and search for new opportunities either in a wage-earning job or as a serial entrepreneur.

Another line of argument is based on selection issues. This argument postulates that opportunity entrepreneurs have a higher level of education or a higher entrepreneurial skill set than do necessity entrepreneurs. According to this argument, opportunity entrepreneurs should stay longer in self-employment than necessity entrepreneurs. However, once the higher set of skills is controlled for, the difference between the two groups should go away. The problem with this analysis is that due to their rather generalist nature (Lazear, 2004; Wagner, 2003), entrepreneurial skills are difficult to measure. In this paper, we refrain from this generalist point of view and compare the two groups using only formal education (the variable years of education), and whether they have been educated in the professional area where they start their venture (the variable educated in this profession).

\subsection{Other Determinants of Survival in Self-employment}

There are several other determinants that influence the success of an entrepreneur. In this subsection, we focus only on those determinants where ex-ante it is not clear whether they have a positive or negative effect on the probability of survival in self-employment; in this case, those determinants are education and financial endowment. For a more detailed and concise review of the literature, readers may consult van Praag (2003) or Schwarz et al. (2005). Table 
A1 summarizes our prior knowledge about the impacts of the various other factors. The relevant empirical literature that supports our knowledge is also referenced in Table A1.

Education is found to have an impact on the success of the venture. Human capital theory suggests that the higher the level of education and the more closely the type of education matches with the requirements of entrepreneurship, the more successful the venture will be (Becker, 1962, 1964; Schultz, 1961). Further, the theory of absorptive capacity (Cohen and Levinthal, 1990) would suggest that the greater ability an entrepreneur has to recognize the value of external information and apply it to commercial ends, the more success she will have as an entrepreneur. To the degree that this ability is correlated with education, education should have a positive impact on the success of the venture. In the context of our research question, however, the impact of education on the probability of survival in self-employment is ex ante unclear. On the one hand, human capital theory and the theory of absorptive capacity both suggest a positive impact; the entrepreneur's probability of success (and, correspondingly, her probability of survival in self-employment) should increase with a higher level of human capital or a higher level of absorptive capacity. On the other hand, better educated business owners might have more interesting alternatives in paid employment than less educated entrepreneurs, which might shorten their stay in self-employment. Another argument for a negative impact of education on self-employment duration is an argument about signaling in the market for wage-earning jobs. Very determined entrepreneurs do not consider a regular wage-earning job as an alternative, and therefore they do not need a high level of formal education as a signaling device. They invest less time and/or less money in formal education, which would predict a negative impact of level of education on self-employment duration (for more on this argument, see Riley, 1979). In a nutshell, the effect of education on staying in self-employment remains unclear, as theoretical arguments exist for both a positive and a negative impact of education. 
The entrepreneur's level of capital endowment might positively influence her propensity to remain an entrepreneur. A high level of capital endowment makes an entrepreneur independent from the success of her venture, since she does not have to rely on revenues from her business to earn her living. Even in hard times, she is able to engage in entrepreneurship. $\mathrm{Ce}$ teris paribus, this argument would predict a positive impact of capital endowment on selfemployment duration. On the other hand, the same argument can also be used to motivate the opposite case. Once the non-monetary returns from entrepreneurship go away, a "richer" business owner can afford to stay away from entrepreneurship (for more on the non-monetary returns of entrepreneurship, see Benz, 2005; Benz and Frey, 2004; Hundley, 2001). In light of these two conflicting arguments, the impact of the entrepreneur's capital endowment on survival in self-employment remains unclear. For a deeper analysis of the relationship between financial capital endowment and venture performance, we refer to Cooper et al. (1994).

\section{Data, Descriptive Statistics and Econometric Models}

\subsection{Data and Descriptive Statistics}

We use the data of the German Socio-Economic Panel Study (GSOEP) at the German Institute for Economic Research (DIW), Berlin, to construct an unbalanced panel data set. ${ }^{3}$ The GSOEP is frequently used in labor economics research, but is only rarely used in entrepreneurship research. To our knowledge, the study by Reize (2000) is the only entrepreneurship study that uses a hazard rate analysis with GSOEP data. The GSOEP is a longitudinal household survey conducted annually. Amongst a broad array of detailed information, it reveals the participant's occupational status (e.g., employee or self-employed). The first wave, in the year 1984, included 12,245 individuals. Since then, the GSOEP has expanded its sample size in several steps, interviewing 22,019 individuals in 2004. To construct our estimation sample,

\footnotetext{
${ }^{3}$ For more about the GSOEP, please refer to Frick (2005).
} 
we make use of the responses from 1990 to $2003^{4}$, select those persons who are self-employed (for at least one year) and study how they came to begin self-employment. Those reporting to have left their previous job in paid employment on their own are classified as opportunity entrepreneurs, whereas those who were either dismissed by their employer or laid off due to a closing down of their workplace are classified as necessity entrepreneurs. Table B3 gives the exact wording of the classifying question and the corresponding answer categories. We constrain our sample to those cases where the termination of the last job, whether voluntary or involuntary, occurred at maximum two years before moving into self-employment. For serial entrepreneurs, we only consider their first entrepreneurial activity. ${ }^{\mathbf{5}}$ Individuals working in a business owned by their family (which could be treated as an indirect mode of selfemployment) are excluded completely. ${ }^{\mathbf{6}}$

Our sample contains 606 entrepreneurs (2,443 observations), of which 174 (28.7\%) are necessity entrepreneurs and $432(71.3 \%)$ are opportunity entrepreneurs. Our method of defining necessity and opportunity entrepreneurship captures only a fraction of all self-employed respondents to the GSOEP (Table B1). There are two reasons for this: (1) for some entrepreneurs, there is insufficient information about how they got into self-employment, and (2) some response categories do not match with either type of entrepreneurship considered in this study. ${ }^{7}$ However, we believe this issue to be of little concern since the proportions of necessity and opportunity entrepreneurship are consistent with survey data from other data sources, particularly the GEM and the Regional Entrepreneurship Monitor data. In addition, the descriptive statistics indicate a rather similar sample composition (e.g., Lückgen and Oberschachtsiek, 2004; Sternberg et al., 2006; Wagner, 2005). Table B2 compares our sample and its characteristics with related studies regarding (1) share of necessity entrepreneurs, (2) share

\footnotetext{
${ }^{4}$ We excluded the six waves from 1984 to 1989, since only West German entrepreneurs would be included, leading to a systematic bias of the dependent variable duration in self-employment.

5 See Alsos and Kolvereid (1998) for a discussion of start-ups by serial entrepreneurs.

6 See Parker (2004) for a description of the problems associated with unpaid family workers.

7 For the response categories that do not match with necessity or opportunity entrepreneurship, see Table B3.
} 
of female entrepreneurs, and (3) mean age. Except for the study by Pfeiffer and Reize (2000), all studies report a share of necessity entrepreneurs similar to that in our study. The lower share of necessity entrepreneurs in the study by Pfeiffer and Reize (2000) (6.7\%) might be explained by the fact that their study relies on firm rather than individual data.

\section{[Insert Table 1 about here]}

Table 1 compares necessity and opportunity entrepreneurs using descriptive statistics. With both types of entrepreneurship, the proportion of men is higher than the proportion of women (67\% or $66 \%$ ); this is in line with other research (e.g., Fairlie and Meyer, 1996; Wagner, 2004). Like Wagner (2005), we find necessity entrepreneurs to be significantly older than opportunity entrepreneurs (38.02 years vs. 35.41 years, with $\mathrm{p}<0.001)$. This finding might also explain why necessity entrepreneurs are more likely to be home owners than opportunity entrepreneurs (43\% vs. 36\%). The situation changes when it comes to household income, where no significant difference is found $(31,970 €$ per year vs. $35,176 €$ per year, with $\mathrm{p}>0.1)$. The proportion of entrepreneurs living in East Germany is significantly higher among necessity entrepreneurs than among opportunity entrepreneurs (42\% vs. $21 \%$ ), which might be a result of the high unemployment in that region (e.g., von Hagen et al., 2002). ${ }^{\mathbf{8}}$ In addition, the proportion of those starting a business in a profession in which they are educated is lower among necessity than it is among opportunity entrepreneurs (35\% vs. $44 \%$ ). Finally, necessity entrepreneurs earn significantly less than opportunity entrepreneurs $(1,786 €$ vs. $2,320 €$ per month, with $\mathrm{p}<0.001)$. No significant differences are found in terms of years of education, nationality, actual working time, marital status, or number of children. One particular finding that may be interpreted as support for our categorization of necessity and opportunity entre-

\footnotetext{
${ }^{8}$ The high share of East Germans in our sample is also due to deliberate oversampling in the GSOEP (Haisken-DeNew and Frick, 2003).
} 
preneurship is that necessity entrepreneurs are significantly less satisfied with their occupational situation than are opportunity entrepreneurs $(6.77 \text { vs. } 7.82 \text {, with } p<0.001)^{9}$.

Finally, the way that the dependent variable duration in self-employment is constructed is explained in more detail. The variable duration in self-employment is calculated as the number of succeeding years that the individual receives income from self-employment. Any interruption for a minimum of one year is interpreted as an exit from self-employment. Individuals for whom there is no indication of the year in which they selected into self-employment, i.e., those for whom survival time is left censored, are excluded from our sample. Those individuals who survive in the status of self-employment beyond the observation time, i.e., those for whom survival time is right censored, are included in the sample but marked with a censoring parameter (this includes 281 entrepreneurs, or $46.37 \%$ of all entrepreneurs). Table B3 describes all of the variables that were used in this paper.

\subsection{Econometric Models}

To compare necessity and opportunity entrepreneurs, we estimate two Probit models (Wooldridge, 2002a, pp. 530-534). The models are estimated using maximum likelihood. The probability that an individual with the related characteristic vector $\mathbf{W}$ is an opportunity entrepreneur is

$$
\operatorname{Pr}(y=1 \mid \mathbf{W})=\Phi\left(\alpha+\beta^{\prime} \mathbf{W}\right),
$$

where $y$ is a dummy variable indicating that an individual is an opportunity entrepreneur, $\beta^{\prime}$ is a vector of coefficients, and $\alpha$ is an intercept. $\Phi(z)$ is the normal cumulative distribution function with

\footnotetext{
${ }^{9}$ The GSOEP asks the participants to report job satisfaction on a scale from 1 (totally unhappy) to 10 (totally happy). Frey and Benz (2003) discuss this scale in more detail.
} 


$$
\Phi(z) \equiv \int_{-\infty}^{z} \phi(v) d v
$$

where $\phi(z)$ is the standard normal density

$$
\phi(z)=\frac{1}{\sqrt{2 \pi}} e^{-\frac{1}{2} z^{2}} .
$$

To study the determinants of the individual duration in self-employment, we estimate several hazard rate models, which are the appropriate models for the study of durations of any kind (Brüderl et al., 1992; van Praag, 2003). As the duration variable is measured in discrete time intervals (years), we specify a discrete time model. In addition, we assume that the cumulative distribution of all exit decisions over time is logistic, which is in line with the contributions of others (e.g., van Praag, 2003). Duration dependence is specified in flexible piecewise constants, which implies that we do not need to assume that all individuals will exit selfemployment as time approaches infinity. To estimate the model, we follow Jenkins (1995) and take advantage of the close relationship between generalized linear models and discrete time hazard rate models. Technically, the estimation is carried out with STATA's xtlogit command, which we applied to the survey data after it was reorganized in person-period format. We also estimated a complimentary log-log model, which can also be applied to discrete time data. The main results stay the same and are available from the corresponding author.

We are interested in the probability of the participant exiting the status of non-adopter at $t$, given that she did not adopt until $t$ (hazard rate). The discrete time hazard rate function is specified as

$$
h(s \mid X)=\frac{1}{1+\exp \left(-\alpha_{s} \theta_{s}-\bar{\beta} \bar{X}-\delta_{i}\right)},
$$


where $h(s \mid X)$ is the hazard rate over the period $s$ with $t_{s-1} \leq t<t_{s}$ for $\mathrm{s}=2, \ldots, \mathrm{S}, \theta_{s}$ is a vector of period indicator variables, $\alpha_{s}$ is the period-specific baseline hazard rate, $\beta$ denotes the parameter vector relating to the individual vector of covariates $X$, and $i=1, \ldots, N$ denotes individuals in the sample.

The individual level error component $\delta_{i}$ controls for the potential influence of unobserved individual characteristics on the hazard rate. Following usual conventions, we model random individual effects and assume that $\delta_{i}$ is normally distributed with zero mean, and that $\delta_{i}$ is independent from all observable characteristics. Conveniently, this also allows us to measure the extent to which the unobserved individual characteristics influence the timing of exit decisions. The relative importance of $\delta_{i}$ is measured as $\rho=\sigma_{\delta}^{2} /\left(\sigma_{\delta}^{2}+1\right)$, which is the proportion of the total unexplained variance that is contributed by individual-specific effects (Wooldridge, 2002b, pp. 477-478).

\section{4. $\quad$ Estimation Results}

\subsection{Probit Models: The Characteristics of Necessity and Opportunity Entrepreneurs}

Table 2 shows the results of two Probit regression models that were estimated to reveal differences between the two types of entrepreneurs. The first model includes age as a single term; the second model assumes a non-linear relationship between the age and type of entrepreneurs, and it includes both age and age squared. For both models, we report coefficients as well as marginal effects.

[Insert Table 2 about here]

The results show that the probability of belonging to the group of opportunity entrepreneurs decreases with residence in East Germany and increases with the level of financial resources 
(i.e., with the variable household income). Contrary to our findings from the univariate statistics, the Probit models do not suggest a difference between necessity and opportunity entrepreneurs for the variables unemployment duration and educated in this profession. An F-test, which tests for the joint influence of time dummies, turned out to be significant $(\mathrm{p}=0.003$, Model II). However, to our surprise, an F-Test for the joint influence of industry dummies produced insignificant results ( $\mathrm{p}=0.256$, Model II). The effect of the variable age is difficult to interpret. Model I suggests a significant negative influence of a higher age on the probability of being an opportunity entrepreneur $(\beta=-0.016$ with $\mathrm{p}<0.05)$; Model II shows an insignificant influence of the variables age and age squared. An F-test for the joint influence of both terms, however, produces weakly significant results $(\mathrm{p}=0.07)$. Both models classify about $73 \%$ of all entrepreneurs correctly.

It may be noteworthy to mention that the results of the Probit models cannot be interpreted as determinants of becoming an opportunity entrepreneur or a necessity entrepreneur; they only reveal differences between the two groups. The reason is that all individuals, who do not become self-employed and all persons that are self-employed for other reasons than being necessity- or opportunity-driven, are excluded in our sample.

\subsection{Hazard Rate Models: The Determinants of Survival in Self-Employment}

Tables B4 and B5 show the descriptive statistics and the correlations of the variables entered into the hazard rate models. Table 3 presents five differently specified hazard rate models. A positive coefficient means that the hazard (i.e., the exit from self-employment) increases with a higher value of the respective variable. In other words, a positive coefficient indicates a negative impact of the respective variable on survival time, whereas a negative coefficient 
indicates a positive impact. In all models, no significant unobserved heterogeneity is found. This is indicated by $\rho$, which is not significantly different from zero in any of the models. ${ }^{10}$

\section{[Insert Table 3 here]}

What do the results of the different hazard rate models show about the determinants of selfemployment duration? Regarding the main research question, only the first model shows a marginally significant result $(\mathrm{p}<0.1)$. After controlling for time variables as well as sociodemographic variables such as age, nationality, and gender, opportunity entrepreneurs survive significantly longer in the status of self-employment than do necessity entrepreneurs $(\beta=-0.28$ with $\mathrm{p}<0.1$, Model I). This effect, however, is no longer significant once educational variables are controlled for (Model II). Since no difference is found regarding the variable education duration, we attribute this effect to the variable educated in this profession, which describes whether the entrepreneur is educated in the professional area where she starts her venture (Table 1). An inclusion of the variable household income (Model III) as well as regional (Model IV) or industry variables (Model V) does not change this main result. We therefore conclude that the mere fact of whether an entrepreneur started her venture for necessity or opportunity reasons does not have a significant impact on her duration in self-employment. The univariate difference between the two groups (3.4 years for necessity vs. 4.3 years for opportunity entrepreneurs, with $\mathrm{p}<0.01$, Table 1) is due to selection. In other words, ceteris paribus, there is no expected difference between the self-employment duration of an opportunity entrepreneur and that of a necessity entrepreneur.

We find an interesting result with regard to German versus non-German entrepreneurs. As with necessity and opportunity entrepreneurs, a test on the equality of means suggests a strong difference in self-employment duration between the two groups. For German entrepreneurs,

\footnotetext{
${ }^{10}$ This applies also to the complimentary log-log model.
} 
we find a mean self-employment length of 4.1 years, whereas for non-German entrepreneurs, we observe only 3.4 years $(\mathrm{p}<0.05)$. However, in the hazard rate analysis, only Model I shows a significant result for the variable German ( $\beta=-0.399$ with $\mathrm{p}<0.05$, Model I). As with necessity and opportunity entrepreneurs, once we control for educational variables, this difference goes away (Model II). Controlling for further variables such as household income as well as regional and industry variables does not change this result (Models III-V). Our conclusion is the same as with necessity and opportunity entrepreneurs: the significant difference in mean self-employment duration is not an original effect but rather is due to selection.

A few results stand out regarding the other variables that were entered into the hazard regression models. The relationship between age and survival in the state of self-employment seems to be curvilinear, which is in line with our ex-ante expectations (Table A1). The region where the venture is started does not have a significant impact on survival time, as the result of the F-test demonstrates $(\mathrm{p}=0.848$ in Model V). However, these regional effects were measured only on the level of federal states, which is a highly aggregated level. These results might change when regional effects are measured on a less aggregated level (see also Fritsch et al., 2006). In all hazard rate models, gender turned out to be a significant determinant; male entrepreneurs survive significantly longer in self-employment than female entrepreneurs $(\beta=-$ 0.433 with $\mathrm{p}<0.01$, Model V). Time effects seem to play no role. An F-test on the joint effect of year dummies is rejected in all models. On the contrary, industry dummies have a significant effect on self-employment duration, as the result of the F-test suggests $(p<0.001$ in Model V). Family variables such as being married or having children do not have a significant impact on the survival rate in any of the models.

\subsection{Limitations}

Although the data are of high quality, some shortcomings remain. Industry dummies are only on a 2-digit level. Furthermore, the exact reasons for business dissolution remain unclear; the 
data do not indicate whether the business owner was forced to leave self-employment or whether it was a voluntary decision. Finally, the distinction between opportunity and necessity entrepreneurs could be further improved. For example, we do not know whether an individual is voluntarily dismissed to be entitled to compensation. From an econometric perspective, estimating a competing risks model would be promising. The problem is that for this purpose, more information is needed about the exact reasons of business dissolution. A larger sample size would allow us to estimate separate regressions for necessity and opportunity entrepreneurs, thereby providing more information about group-specific determinants or duration dependence. Another potential problem is the fact that our sample captures only a subgroup of all would-be entrepreneurs. Those who try to establish a venture but never arrive in the state of self-employment are not considered.

\section{Policy Implications and Further Research}

The German state gives monetary incentives to engage in start-ups. Some of these subsidies are open to every kind of start-up, while some are only for particular types of start-ups. For example, the federal employment agency ("Bundesagentur für Arbeit") only promotes entrepreneurs who were previously unemployed (e.g., payments under the so-called "Ich-AG"11). These programs are designed for necessity entrepreneurs rather than for opportunity entrepreneurs, and are of an enormous size; in 2004, more than half of all German start-ups (about 320,000) were supported by the federal employment agency (Bundesministerium für Wirtschaft und Technologie, 2006; Sandner et al. 2007; Niefert and Tchouvakhina, 2006). Based on our empirical results, two particular policy implications stand out. First, it makes sense to support necessity entrepreneurs. After controlling for educational variables, their chances of survival in self-employment are not worse than those of opportunity entrepreneurs.

\footnotetext{
${ }^{11}$ Under the "Ich-AG" program, a start-up entrepreneur was granted a monthly subsidy of $600 €$ in the $1^{\text {st }}$ year, $360 €$ in the $2^{\text {nd }}$ year, and $240 €$ in the $3^{\text {rd }}$ year of the start-up (data from 2005). The so called "Überbrückungsgeld" (bridging allowances) constitutes another subsidy designed for start-ups out of unemployment. Hinz and Jungbauer-Gans (1999) as well as Pfeiffer and Reize (2000) describe the programme in more detail.
} 
Second, the economic efficiency of these programs could be further improved; if a necessity entrepreneur starts her venture in a profession of her expertise, her chances of survival in selfemployment increase substantially. Therefore, a promising approach could be to guide necessity entrepreneurs towards fields within their particular expertise. The inclusion of such criteria by instruments of an active labor market policy in November 2004 was therefore a move in the right direction. ${ }^{12}$

A caveat remains: these policy implications should be interpreted cautiously, since we do not have micro data on the amount of governmental benefits that were granted. Such data would allow a better assessment of the impact of governmental start-up programs. In addition, we analyzed only one element of entrepreneurial success, the entrepreneur's duration in selfemployment. To learn more about potential positive external effects (e.g., jobs created), more data is needed on the size and growth of the respective ventures.

There is a great deal of potential for further research in this area. For example, some GEMrelated research suggests that a high rate of opportunity entrepreneurs is preferable, whereas a high rate of necessity entrepreneurs is less desirable (e.g., Acs et al., 2005; Acs and Varga, 2005). However, the results of our econometric analyses do not lead to such a clear answer. Controlling for educational variables, we do not find a significant difference between selfemployment durations among the two groups. Following this counterintuitive result, further (empirical) research might address the dimensions of success in which opportunity entrepreneurs are more successful than necessity entrepreneurs, if any. A second avenue of research would be to analyze whether the determinants of success differ between the two groups. Finally, from a theoretical perspective, a conceptual framework that addresses the impact of a necessity-based motivation on the success of the venture would be helpful in guiding the discussion.

\footnotetext{
${ }^{12}$ For more information on the adjustments, see Bundesministerium für Wirtschaft und Technologie (2006).
} 
Table 1: Necessity vs. Opportunity Entrepreneurs.

\begin{tabular}{|c|c|c|c|c|c|c|}
\hline \multirow[b]{2}{*}{ Variables } & \multicolumn{2}{|c|}{$\begin{array}{c}\text { Opportunity } \\
\text { Entrepreneurs }\end{array}$} & \multicolumn{2}{|c|}{$\begin{array}{c}\text { Necessity } \\
\text { Entrepreneurs }\end{array}$} & \multicolumn{2}{|c|}{$\begin{array}{l}\text { Opp. vs. Nec. } \\
\text { Entrepreneurs }\end{array}$} \\
\hline & Mean & Std. dev. & Mean & Std. dev. & t-test & $\chi^{2}$-test \\
\hline Exit (1=yes) & 0.46 & & 0.48 & & & 0.677 \\
\hline Duration (years) & 4.29 & 3.39 & 3.40 & 2.81 & 0.002 & \\
\hline Working time (h/week) & 45.73 & 17.02 & 43.87 & 16.53 & 0.267 & \\
\hline Job satisfaction $(0-10)$ & 7.82 & 1.92 & 6.77 & 2.33 & 0.000 & \\
\hline East Germany (1=yes) & 0.21 & & 0.42 & & & 0.000 \\
\hline German (1=yes) & 0.86 & & 0.87 & & & 0.632 \\
\hline Age at time of entry (years) & 35.41 & 9.02 & 38.02 & 9.60 & 0.002 & \\
\hline Male (1=yes) & 0.66 & & 0.67 & & & 0.765 \\
\hline Education duration (years) & 12.74 & 2.89 & 12.60 & 2.80 & 0.602 & \\
\hline Educated in this profession(1=yes) & 0.44 & & 0.35 & & & 0.028 \\
\hline Earnings (1000€/month) & 2.32 & 1.72 & 1.79 & 1.32 & 0.001 & \\
\hline Household income (1000€/year) & 35.18 & 23.51 & 31.97 & 23.01 & 0.127 & \\
\hline Home ownership (1=yes) & 0.36 & & 0.43 & & & 0.156 \\
\hline Unemployment duration (months) & 4.81 & 11.60 & 8.25 & 10.80 & 0.001 & \\
\hline Married (1=yes) & 0.57 & & 0.61 & & & 0.427 \\
\hline Children (1=yes) & 0.50 & & 0.46 & & & 0.428 \\
\hline
\end{tabular}

Note: The t-test column shows the p-values of the t-test on the equality of means, whereas the $\chi^{2}$-test column shows the p-values of the test on the equality of proportions. A p-value of less than 0.05 means that the null-hypothesis can be rejected at an error level of less than 5 percent. Calculations are on first year observations in self-employment.

$\mathrm{N}$ : 606, including 432 opportunity entrepreneurs $(71.3 \%)$ and 174 necessity entrepreneurs $(28.7 \%)$

Data source: GSOEP 1989-2003 
Table 2: Estimated Probability of Being An Opportunity Entrepreneur (Dependent Variable: Opportunity Entrepreneur).

\begin{tabular}{|c|c|c|c|c|c|c|c|c|}
\hline \multirow[b]{3}{*}{ Variables } & \multicolumn{4}{|c|}{ Estimation of coefficients } & \multicolumn{4}{|c|}{ Estimation of marginal effects } \\
\hline & \multicolumn{2}{|c|}{ Model I } & \multicolumn{2}{|c|}{ Model II } & \multicolumn{2}{|c|}{ Model I } & \multicolumn{2}{|c|}{ Model II } \\
\hline & Coef. & Std. err. & Coef. & Std. err. & $d F / d x$ & Std. err. & $\mathrm{dF} / \mathrm{dx}$ & Std. err. \\
\hline \multicolumn{9}{|l|}{ Socio-demographic variables } \\
\hline Male $^{1}$ & -0.136 & 0.136 & -0.138 & 0.136 & -0.043 & 0.042 & -0.044 & 0.042 \\
\hline German $^{1}$ & 0.057 & 0.178 & 0.055 & 0.178 & 0.019 & 0.059 & 0.018 & 0.059 \\
\hline Married $^{1}$ & -0.078 & 0.148 & -0.068 & 0.148 & -0.025 & 0.047 & -0.022 & 0.047 \\
\hline Children $^{1}$ & 0.097 & 0.130 & 0.118 & 0.136 & 0.031 & 0.042 & 0.038 & 0.044 \\
\hline Age & $-0.016^{*}$ & 0.007 & -0.042 & 0.047 & $-0.005^{*}$ & 0.002 & -0.014 & 0.015 \\
\hline $\mathrm{Age}^{2}$ & & & 0.0003 & 0.0006 & & & 0.0001 & 0.0002 \\
\hline East German ${ }^{1}$ & $-0.712^{* * *}$ & 0.138 & $-0.713^{* * * *}$ & 0.138 & $-0.248^{* * *}$ & 0.050 & $-0.248^{* * *}$ & 0.050 \\
\hline \multicolumn{9}{|l|}{ Education and job variables } \\
\hline Education duration & 0.017 & 0.024 & 0.020 & 0.025 & 0.006 & 0.008 & 0.007 & 0.008 \\
\hline Educated in this profession ${ }^{1}$ & 0.179 & 0.128 & 0.181 & 0.127 & 0.057 & 0.040 & 0.058 & 0.040 \\
\hline Unemployment duration & -0.008 & 0.006 & -0.008 & 0.006 & -0.003 & 0.002 & -0.003 & 0.002 \\
\hline \multicolumn{9}{|l|}{ Financial variable } \\
\hline Log (household income) & $0.266^{*}$ & 0.115 & $0.262^{*}$ & 0.114 & $0.086^{*}$ & 0.037 & $0.084^{*}$ & 0.037 \\
\hline $\begin{array}{l}\text { Industry dummies } \\
\text { (reference: retail) }\end{array}$ & \multicolumn{2}{|c|}{$\begin{array}{c}15 \text { categories } \\
(\mathrm{p}=0.274)\end{array}$} & \multicolumn{2}{|c|}{$\begin{array}{c}15 \text { categories } \\
(\mathrm{p}=0.256)\end{array}$} & & & & \\
\hline $\begin{array}{l}\text { Year dummies } \\
\text { (reference category: year 2003) }\end{array}$ & \multicolumn{2}{|c|}{$\begin{array}{l}14 \text { categories } \\
(\mathrm{p}=0.002)\end{array}$} & \multicolumn{2}{|c|}{$\begin{array}{l}14 \text { categories } \\
(\mathrm{p}=0.003)\end{array}$} & & & & \\
\hline Constant & -1.447 & 1.401 & -1.913 & 1.188 & & & & \\
\hline No. of individuals & \multicolumn{2}{|c|}{606} & \multicolumn{2}{|c|}{606} & & & & \\
\hline Pseudo $\mathrm{R}^{2}$ & \multicolumn{2}{|c|}{0.142} & \multicolumn{2}{|c|}{0.141} & & & & \\
\hline $\begin{array}{l}\text { Wald } \chi^{2} \\
\text { p-value }\end{array}$ & \multicolumn{2}{|c|}{$\begin{array}{c}96.7 \\
(<0.001)\end{array}$} & \multicolumn{2}{|c|}{$\begin{array}{c}95.5 \\
(<0.001)\end{array}$} & & & & \\
\hline Log pseudo-likelihood & \multicolumn{2}{|c|}{-311.9} & \multicolumn{2}{|c|}{-312.1} & & & & \\
\hline Percent correctly classified & \multicolumn{2}{|c|}{$73.43 \%$} & \multicolumn{2}{|c|}{$73.60 \%$} & & & & \\
\hline
\end{tabular}


Table 3: Random Effects Hazard Rate Regression Results (Dependent Variable: Status of Self-employment in Year $t$ ).

\begin{tabular}{|c|c|c|c|c|c|c|c|c|c|c|}
\hline \multirow[b]{2}{*}{ Variables } & \multicolumn{2}{|c|}{ Model I } & \multicolumn{2}{|c|}{ Model II } & \multicolumn{2}{|c|}{ Model III } & \multicolumn{2}{|c|}{ Model IV } & \multicolumn{2}{|c|}{ Model V } \\
\hline & Coef. & Std. err. & Coef. & Std. err. & Coef. & Std. err. & Coef. & Std. err. & Coef. & Std. err. \\
\hline Opportunity entrepreneur & $-0.280^{+}$ & 0.153 & -0.223 & 0.153 & -0.197 & 0.154 & -0.220 & 0.166 & -0.074 & 0.175 \\
\hline \multicolumn{11}{|l|}{ Socio-demographic variables } \\
\hline Male & $-0.498^{* * *}$ & 0.142 & $-0.514^{* * *}$ & 0.143 & $-0.479^{* * *}$ & 0.145 & $-0.468^{* * *}$ & 0.152 & $-0.433^{* *}$ & 0.171 \\
\hline German & $-0.399^{*}$ & 0.193 & -0.245 & 0.198 & -0.258 & 0.199 & -0.240 & 0.212 & -0.131 & 0.226 \\
\hline Married & 0.167 & 0.165 & 0.156 & 0.167 & 0.196 & 0.168 & 0.159 & 0.175 & 0.185 & 0.184 \\
\hline Children & 0.056 & 0.157 & 0.003 & 0.157 & 0.022 & 0.158 & 0.076 & 0.165 & 0.060 & 0.174 \\
\hline Age & $-0.191^{* * *}$ & 0.049 & $-0.152^{* *}$ & 0.050 & $-0.154^{* *}$ & 0.050 & $-0.160^{* *}$ & 0.052 & $-0.116^{*}$ & 0.054 \\
\hline $\mathrm{Age}^{2}$ & $0.002^{* * * *}$ & 0.0006 & $0.002^{* *}$ & 0.0006 & $0.002^{* *}$ & 0.0006 & $0.002^{* *}$ & 0.0006 & $0.001^{*}$ & 0.0006 \\
\hline \multicolumn{11}{|l|}{ Education variables } \\
\hline Education duration & & & $-0.056^{*}$ & 0.028 & $-0.051^{+}$ & 0.028 & -0.046 & 0.029 & -0.019 & 0.032 \\
\hline Educated in this profession & & & $-0.412^{* *}$ & 0.145 & $-0.407^{* *}$ & 0.145 & $-0.417^{* *}$ & 0.150 & $-0.304^{+}$ & 0.160 \\
\hline \multicolumn{11}{|l|}{ Financial variable } \\
\hline Log (household income) & & & & & $-0.243^{+}$ & 0.135 & $-0.275^{+}$ & 0.142 & $-0.296^{*}$ & 0.150 \\
\hline $\begin{array}{l}\text { Region dummies } \\
\text { (reference: North Rhine Westphalia) }\end{array}$ & & & & & & & \multicolumn{2}{|c|}{$\begin{array}{l}15 \text { categories } \\
\quad(p=0.887)\end{array}$} & \multicolumn{2}{|c|}{$\begin{array}{c}15 \text { categories } \\
(\mathrm{p}=0.848)\end{array}$} \\
\hline $\begin{array}{l}\text { Industry dummies } \\
\text { (reference: retail) }\end{array}$ & & & & & & & & & \multicolumn{2}{|c|}{$\begin{array}{c}15 \text { categories } \\
(\mathrm{p}<0.001)\end{array}$} \\
\hline $\begin{array}{l}\text { Year dummies } \\
\text { (reference: year 2003) }\end{array}$ & \multicolumn{2}{|c|}{$\begin{array}{l}14 \text { categories } \\
(\mathrm{p}=0.269)\end{array}$} & \multicolumn{2}{|c|}{$\begin{array}{l}14 \text { categories } \\
(\mathrm{p}=0.161)\end{array}$} & \multicolumn{2}{|c|}{$\begin{array}{l}14 \text { categories } \\
(\mathrm{p}=0.228)\end{array}$} & \multicolumn{2}{|c|}{$\begin{array}{l}14 \text { categories } \\
(\mathrm{p}=0.394)\end{array}$} & \multicolumn{2}{|c|}{$\begin{array}{l}14 \text { categories } \\
(\mathrm{p}=0.287)\end{array}$} \\
\hline Duration dummies & \multicolumn{2}{|c|}{14 categories } & \multicolumn{2}{|c|}{14 categories } & \multicolumn{2}{|c|}{14 categories } & \multicolumn{2}{|c|}{14 categories } & \multicolumn{2}{|c|}{14 categories } \\
\hline $\mathrm{N}$ observations & \multicolumn{2}{|c|}{2,443} & \multicolumn{2}{|c|}{2,443} & \multicolumn{2}{|c|}{2,443} & \multicolumn{2}{|c|}{2,443} & \multicolumn{2}{|c|}{2,443} \\
\hline $\mathrm{N}$ individuals & \multicolumn{2}{|c|}{606} & \multicolumn{2}{|c|}{606} & \multicolumn{2}{|c|}{606} & \multicolumn{2}{|c|}{606} & \multicolumn{2}{|c|}{606} \\
\hline Log likelihood & -799 & & -79 & & -79 & & -786 & .02 & & \\
\hline$\rho$ & 0.01 & & 0.0 & & 0.0 & & 0.0 & & & \\
\hline p-value of LL-ratio test of $\rho=0$ & 0.41 & & 0.3 & & 0.3 & & 0.2 & & & \\
\hline
\end{tabular}




\section{Appendix A. Determinants of Survival}

See Table A1 below.

Table A1: Determinants of Survival in Self-employment

\begin{tabular}{|c|c|c|c|}
\hline Determinant & $\begin{array}{c}\text { Predicted sign of } \\
\text { hazard rate } \\
\end{array}$ & $\begin{array}{c}\text { Increase/decrease of } \\
\text { survival } \\
\text { probability } \\
\end{array}$ & Literature \\
\hline Opportunity entrepreneur & $-/+$ & & \\
\hline Male & - & Increase & $\begin{array}{l}\text { Carr (1996); Devine (1994); } \\
\text { Fehrenbach (2002); Schwarz et al. (2005) }\end{array}$ \\
\hline German & $-/+$ & & Light (1972); Portes and Zhou (1996) \\
\hline Married & - & Increase & Brüderl and Preisendörfer (1998) \\
\hline Children & - & Increase & Brüderl and Preisendörfer (1998) \\
\hline Age & - & Increase & $\begin{array}{l}\text { Brüderl et al. (1992); Reuber and Fischer } \\
\text { (1999); Schwarz et al. (2005) }\end{array}$ \\
\hline Age $^{2}$ & + & Decrease & $\begin{array}{l}\text { Brüderl et al. (1992); Sapienza and Grimm } \\
\text { (1997); Schwarz et al. (2005) }\end{array}$ \\
\hline Years of education & - & Increase & $\begin{array}{l}\text { Brüderl et al. (1992); Schiller and Crewson } \\
\text { (1997); van Praag (2003) }\end{array}$ \\
\hline Educated in profession & - & Increase & \\
\hline Financial endowment & $-/+$ & & $\begin{array}{l}\text { Brüderl et al. (1992); Cooper et al. (1994); van } \\
\text { Praag (2003) }\end{array}$ \\
\hline Region dummies & $-/+$ & & Fritsch et al. (2006) \\
\hline Industry dummies & $-/+$ & & Audretsch (1995); Fritsch et al. (2006) \\
\hline Time dummies & $-/+$ & & \\
\hline Duration Dummies & $-/+$ & & Brüderl et al. (1992); Van Praag (2003) \\
\hline
\end{tabular}




\section{Appendix B. Sample, Variables and Descriptive Statistics}

See Tables B1-B5 below.

Table B1: New Entries in Self-employment per Year: Necessity vs. Opportunity Entrepreneurs

\begin{tabular}{|c|c|c|c|c|c|}
\hline Year & $\begin{array}{c}\text { Necessity } \\
\text { Entrepreneurs }\end{array}$ & $\begin{array}{c}\text { Opportunity } \\
\text { Entrepreneurs }\end{array}$ & Total & $\begin{array}{l}\text { All self- } \\
\text { employed in } \\
\text { GSOEP }\end{array}$ & $\begin{array}{l}\text { All successfully inter- } \\
\text { viewed persons in } \\
\text { GSOEP (Frick, 2005) }\end{array}$ \\
\hline 1990 & 6 & 20 & 26 & 1,117 & 13,972 \\
\hline 1991 & 3 & 20 & 23 & 708 & 13,669 \\
\hline 1992 & 12 & 46 & 58 & 656 & 13,397 \\
\hline 1993 & 15 & 44 & 59 & 624 & 13,179 \\
\hline 1994 & 4 & 30 & 34 & 664 & 13,417 \\
\hline 1995 & 13 & 26 & 39 & 641 & 13,768 \\
\hline 1996 & 11 & 29 & 40 & 623 & 13,511 \\
\hline 1997 & 16 & 27 & 43 & 648 & 13,283 \\
\hline 1998 & 8 & 24 & 32 & 685 & 14,670 \\
\hline 1999 & 13 & 21 & 34 & 662 & 14,085 \\
\hline 2000 & 21 & 47 & 68 & 1,367 & 24,586 \\
\hline 2001 & 12 & 35 & 47 & 1,177 & 22,351 \\
\hline 2002 & 14 & 38 & 52 & 1,483 & 23,892 \\
\hline 2003 & 26 & 25 & 51 & 1,324 & 22,592 \\
\hline \multirow[t]{2}{*}{ Total } & 174 & 432 & 606 & 11,259 & 216,400 \\
\hline & $28.7 \%$ & $71.3 \%$ & $100 \%$ & & \\
\hline
\end{tabular}

Data source: GSOEP 1989-2003 
Table B2: Studies on Necessity Entrepreneurship in Germany

\begin{tabular}{|c|c|c|c|c|}
\hline \multirow[b]{3}{*}{ Study } & \multicolumn{4}{|c|}{ Sample Characteristics } \\
\hline & \multirow{2}{*}{$\begin{array}{c}\text { Necessity } \\
\text { entrepreneurs } \\
\text { (in \% of all } \\
\text { entrepreneurs) }\end{array}$} & \multirow{2}{*}{$\begin{array}{c}\text { Female } \\
\text { (in \%) }\end{array}$} & \multicolumn{2}{|c|}{ Age (in years) } \\
\hline & & & Mean & Median \\
\hline Baumgartner and Caliendo $(2007)^{1}$ & & $34.8 \%$ & & $35-39$ \\
\hline Block and Wagner (2007) & $29.5 \%$ & $30.0 \%$ & 38.1 & \\
\hline Hinz and Jungbauer-Gans (1999) & $45.3 \%$ & $30.0 \%$ & 39.3 & \\
\hline Lückgen and Oberschachtsiek (2004) & $26.0 \%$ & & & \\
\hline Pfeiffer and Reize (2000) & $6.7 \%$ & $20.3 \%$ & & $35-39$ \\
\hline Niefert and Tchouvakhina (2006) & $46.3 \%$ & $29.3 \%$ & & $30-44$ \\
\hline Reize $(2000)^{1}$ & & $30.4 \%$ & & $35-39$ \\
\hline Sandner et al. $(2007)^{1}$ & & $31.4 \%$ & 41.1 & \\
\hline Sternberg et al. (2006) & $46.5 \%$ & & & \\
\hline Sternberg et al. (2007) & $34.2 \%$ & & & \\
\hline Wagner (2005) & $33.4 \%$ & $45.0 \%$ & 40.0 & \\
\hline Wießner $(2000)^{1}$ & & $25.9 \%$ & & $35-39$ \\
\hline
\end{tabular}

${ }^{1}$ These studies consider only unemployed founders; no comparison to other types of founders is made. 
Table B3: Description of Variables

\section{Categorial variables}

Exit

Opportunity entrepreneur

Educated in this profession

Male

German *

Married *

Home ownership *

Children *

Industry dummies

Region dummies *

Year dummies

Duration dummies

\section{Duration}

Household income *

Gross earnings

Working time

Age

Education duration
East Germany *

\section{Continuous variables}

Job satisfaction

\section{Description}

Dummy for an individual who left self-employment.

Dummy for an entrepreneur who quit her last job on her own. The wording of the question in the GSOEP is: "How was this job terminated?". The corresponding answer categories are: "Because your place of work or office has closed" (7.7 \%), "My resignation" (32.9\%), "Dismissal" (18.3 \%), "Mutual agreement" $(10.4 \%)$, "A temporary job or apprenticeship had been completed" (15.7\%), "Reaching retirement age/pension" (7\%), and "Suspension" $(8 \%)$. Answer categories 1 and 3 are interpreted as necessity entrepreneurship; answer category 2 is interpreted as opportunity entrepreneurship. The numbers in brackets refer to the percentage of answers that fell in these categories for the year 2001.

Dummy for an individual who is self-employed in the profession that she has learnt; self-reported by respondent.

Dummy for an individual who is male.

Dummy for an individual who is German by nationality

Dummy for an individual who is married

Dummy for an individual who owns an apartment or house

Dummy for an individual who has at least one child under age 16

Dummy for an individual who lives in East Germany

Dummies for agriculture (NACE 1,2,5), construction (NACE 45), car sale (NACE 50), wholesale (NACE 51), retailing (NACE 52), hotel and restaurant (NACE 55), transportation (NACE 60, 61, 62, 63), banking and insurance (NACE 65, 66, 67), real estate (70), databases (NACE 72), consulting (NACE 74), education sector (NACE 80), health sector (NACE 85), culture and sports (92), manufacturing (NACE 15, 16, 17, 18, 19, 20, 21, 22, 23, $24,26,27,28,29,30,31,32,33,34,35,36,37,40,41,96,97,100)$, and other (NACE 10, 11, 12, 13, 14, 64, 71, 73, 75, 90, 91, 93, 95, 98, 99)

Dummies for Berlin West, Schleswig Holstein, Hamburg, Lower Saxony, Bremen, North Rhine-Westphalia, Hesse, Rhineland-Palatinate, BadenWuerttemberg, Bavaria, Berlin East, Mecklenburg-Western Pomerania, Brandenburg, Saxony Anhalt, Thuringia, and Saxony.

Dummies for the years 1990-2003 in which the individual entered into self-employment.

Dummies for the $1^{\text {st }}, 2^{\text {nd }}, 3^{\text {rd }}$ years, etc., in self-employment.

\section{Description}

No. of years a person has been in self-employment.

Net household income (in 1000€/year); generated by GSOEP.

Monthly gross earnings from self-employment (in €); generated by GSOEP.

Actual working time per week (in hours); generated by GSOEP.

Job satisfaction on a scale from 1 (totally unhappy) to 10 (totally happy).

Current age of an individual in years.

Years of education; generated by GSOEP. The variable is calculated as years of schooling plus years of occupational training. Years of schooling is calculated as follows: no degree $=7$ years, lower school degree $=9$ years, intermediary school $=10$ years, degree for a professional college $=12$ years, high school degree $=13$ years. Years of occupational training is calculated as follows: apprenticeship $=1.5$ years, technical schools (incl. health) $=2$ years, civi servants apprenticeship $=1.5$ years, higher technical college $=3$ years, university degree $=5$ years .

Unemployment duration

* measured in the year before the individual entered into self-employment

For more information on the exact wording of the questions, please refer to http://www.diw.de/english/sop/service/fragen/index.html (Sep.,17, 2007)

For more information on data quality, please refer to http://www.diw.de/english/sop/service/dataquality/index.html (Sep., 17, 2007). 
Table B4: Descriptive Statistics

\begin{tabular}{|c|c|c|c|c|}
\hline Variable & Mean & Std. dev. ${ }^{1}$ & Min & Max \\
\hline Opportunity entrepreneur & 0.713 & & 0.000 & 1.000 \\
\hline Male & 0.663 & & 0.000 & 1.000 \\
\hline German & 0.863 & & 0.000 & 1.000 \\
\hline Age & 36.162 & 9.258 & 18.000 & 75.000 \\
\hline Married & 0.584 & & 0.000 & 1.000 \\
\hline Children & 0.485 & & 0.000 & 1.000 \\
\hline Education duration & 12.696 & 2.866 & 7.000 & 18.000 \\
\hline Educated in this profession & 0.414 & & 0.000 & 1.000 \\
\hline Household income & 34.255 & 23.398 & 2.871 & 234.613 \\
\hline Berlin West & 0.030 & & 0.000 & 1.000 \\
\hline Schleswig Holstein & 0.026 & & 0.000 & 1.000 \\
\hline Hamburg & 0.023 & & 0.000 & 1.000 \\
\hline Lower Saxony & 0.071 & & 0.000 & 1.000 \\
\hline Bremen & 0.013 & & 0.000 & 1.000 \\
\hline North Rhine Westphalia & 0.188 & & 0.000 & 1.000 \\
\hline Hesse & 0.078 & & 0.000 & 1.000 \\
\hline Rhineland and Saarland & 0.059 & & 0.000 & 1.000 \\
\hline Baden Wurttemberg & 0.130 & & 0.000 & 1.000 \\
\hline Bavaria & 0.111 & & 0.000 & 1.000 \\
\hline Berlin East & 0.033 & & 0.000 & 1.000 \\
\hline Mecklenburg-Western Pomerania & 0.031 & & 0.000 & 1.000 \\
\hline Brandenburg & 0.040 & & 0.000 & 1.000 \\
\hline Saxony Anhalt & 0.041 & & 0.000 & 1.000 \\
\hline Thuringia & 0.053 & & 0.000 & 1.000 \\
\hline Saxony & 0.073 & & 0.000 & 1.000 \\
\hline Agriculture & 0.023 & & 0.000 & 1.000 \\
\hline Construction & 0.119 & & 0.000 & 1.000 \\
\hline Car sale & 0.015 & & 0.000 & 1.000 \\
\hline Wholesale & 0.015 & & 0.000 & 1.000 \\
\hline Retail & 0.122 & & 0.000 & 1.000 \\
\hline Transportation & 0.056 & & 0.000 & 1.000 \\
\hline Hotel and restaurant & 0.058 & & 0.000 & 1.000 \\
\hline Banking and insurance & 0.051 & & 0.000 & 1.000 \\
\hline Real estate & 0.012 & & 0.000 & 1.000 \\
\hline Consulting & 0.091 & & 0.000 & 1.000 \\
\hline Databases & 0.031 & & 0.000 & 1.000 \\
\hline Education & 0.025 & & 0.000 & 1.000 \\
\hline Health & 0.069 & & 0.000 & 1.000 \\
\hline Culture and sports & 0.015 & & 0.000 & 1.000 \\
\hline Manufacturing & 0.112 & & 0.000 & 1.000 \\
\hline Other sectors & 0.063 & & 0.000 & 1.000 \\
\hline
\end{tabular}


Table B5: Correlations

\begin{tabular}{|c|c|c|c|c|c|c|c|c|}
\hline & 1. & 2. & 3. & 4. & 5. & 6. & 7. & 8. \\
\hline \multicolumn{9}{|l|}{ 1. Opportunity entrepreneur } \\
\hline 2. Male & -0.0122 & & & & & & & \\
\hline 3. German & -0.0194 & -0.0603 & & & & & & \\
\hline 5. Married & -0.0322 & -0.0271 & -0.0634 & $0.3438^{* * *}$ & & & & \\
\hline 6. Children & 0.0322 & 0.0138 & $-0.0935^{*}$ & -0.0552 & $0.3903^{* * * *}$ & & & \\
\hline 9. Household income & 0.0620 & 0.0448 & 0.0437 & $0.1776^{* * *}$ & $0.1541^{* * * *}$ & 0.0315 & $0.1719^{* * * *}$ & $0.0917^{*}$ \\
\hline
\end{tabular}

N: 606

Data source: GSOEP 1989-2003 


\section{References}

Acs, Z. J., Arenius, P., Hay, M. and M. Minniti. (2005). “Global Entrepreneurship Monitor 2004 Executive Report.” Babson College, London Business School.

Acs, Z. J. and A. Varga. (2005). "Entrepreneurship, Agglomeration and Technological Change." Small Business Economics 24, 323-334.

Alsos, G. A. and L. Kolvereid. (1998). “The Business Gestation Process of Novice, Serial, and Parallel Business Founders.” Entrepreneurship Theory and Practice 22, 101-114.

Audretsch, D. B. (1995). "Innovation and Industry Evolution.” Cambridge (MA): MIT Press.

Baumgartner, H. J. and M. Caliendo (2007). “Turning Unemployment into Self-Employment: Effectiveness and Efficiency of Two Start-Up Programmes.” IZA Discussion Paper No. 2660.

Becker, G. (1962). "Investment in Human Capital: A Theoretical Analysis." The Journal of Political Economy 70, 9-49.

Becker, G. (1964). "Human Capital.” Chicago: University of Chicago Press.

Benz, M. (2005). "Entrepreneurship as a Non-profit-seeking Activity.” Institute for Empirical Research in Economics Working Paper No. 243, University of Zurich.

Benz, M. and B. S. Frey. (2004). “Being Independent Raises Happyness at Work.” Swedish Economic Policy Review 11, 95-134.

Bergmann, H. and R. Sternberg. (2007). "The Changing Face of Entrepreneurship in Germany." Small Business Economics 28, 205-221.

Blanchflower, D. (2000). "Self-employment in OECD Countries." Labour Economics 7, 471-505. 
Block, J. and M. Wagner (2007). “Opportunity Recognition and Exploitation by Necessity and Opportunity Entrepreneurs: Empirical Evidence from Earnings Equations." In George T. Solomon (ed.), Proceedings of the Sixty-Sixth Annual Meeting of the Academy of Management (CD), ISSN 1543-8643.

Brüderl, J., Preisendörfer, P. and R. Ziegler. (1992). "Survival Chances of Newly Founded Founded Business Organizations.” American Sociological Review 57, 227-242.

Brüderl, J. and P. Preisendörfer. (1998). "Network Support and the Success of Newly Founded Businesses.” Small Business Economics 10, 213-225.

Bundesministerium für Wirtschaft und Technologie. (2006). "Jahreswirtschaftsbericht 2006." Berlin.

Carr, D. (1996). “Two Paths to Self-Employment? Women's and Men's Self-Employment in the United States, 1980.” Work and Occupations 23, 26-53.

Cohen, W. M. and D. A. Levinthal (1990). “Absorptive Capacity: A New Perspective on Learning and Innovation.” Administrative Science Quarterly 35, 128-152.

Cooper, A. C., Gimeno-Gascon, F. J. and C. Y. Woo. (1994). "Initial Human and Financial Capital as Predictors of New Venture Performance." Journal of Business Venturing 9, 371-395.

Davidson, P. and Honig, B. (2003). "The Role of Social and Human Capital among Nascent Entrepreneurs.” Journal of Business Venturing 18, 301-331.

Devine, T. J. (1994). "Characteristics of Self-employed Women in the United States." Monthly Labor Review 117, 20-34. 
Fairlie, R. W. and B. D. Meyer. (1996). "Ethnic and Racial Self Employment: Differences and Possible Explanations.” Journal of Human Resources 31, 757-793.

Fehrenbach, S. (2002).’'Strukturmerkmale der von Frauen geführten Betriebe in Deutschland.” Institut für Mittelstandsforschung, Universität Mannheim.

Frey, B. S. and M. Benz. (2003). "Being Independent is a Great Thing: Subjective Evaluations of Self-employment and Hierarchy." CESifo Working Paper No. 959, Munich.

Frick, J. R. (2005). “A General Introduction to the German Socio Economic Panel Study (SOEP) - Design, Contents and Data Structure [waves A-U, 1984-2004].” DIW Berlin.

Fritsch, M., Brixy, U. and O. Falck. (2006). "The Effect of Industry, Region, and Time on New Business Survival - A Multi-Dimensional Analysis.” Review of Industrial Organization 28, 285-306.

Gimeno, J., Folta, T., Cooper, A. and C. Woo. (1997). "Survival of the fittest? Entrepreneurial Human Capital and the Persistence of Underperforming Firms." Administrative Science Quarterly 42, 750-783.

Haisken-DeNew, J. P. and J. R. Frick. (2003). "Desktop Companion to the German SocioEconomic Panel.” Manual, DIW Berlin.

Hamilton, B. H. (2000). "Does Entrepreneurship Pay? An Empirical Analysis of the Returns to Self-employment.” Journal of Political Economy 108, 604-631.

Hinz, T. and M. Jungbauer-Gans. (1999). "Starting a Business after Unemployment: Characteristics and Chances of Success (Empirical Evidence from a Regional German Labour Market).” Entrepreneurship and Regional Development 11, 317-333. 
Hundley, G. (2001). "Why and When are the Self-employed More Satisfied With Their Work?” Industrial Relations 40, 293-317.

Jenkins, S. P. (1995). "Easy Estimation Methods for Discrete-Time Duration Models.” Oxford Bulletin of Economics and Statistics 57, 129-38.

Kanbur, S. M. R. (1982). "Entrepreneurial Risk Taking, Inequality, and Public Policy: An Application of Inequality Decomposition Analysis to the General Equilibrium Effects of Progressive Taxation.” Journal of Political Economy 90: 1-21.

Lazear, E. P. (2004). "Balanced Skills and Entrepreneurship.” American Economic Review 94, 208-211.

Light, I. (1972). "Ethnic Enterprises in America: Business Welfare among Chinese, Japanese and Blacks.” Berkeley (CA): University of California Press.

Lückgen, I. and D. Oberschachtsiek. (2004). „Regionaler Entrepreneurship Monitor. Zur Dynamik von Gründungsaktivitäten in Deutschland: Ausmaß und Ursachen.“ Universität zu Köln, Universität Lüneburg.

Meager, N. (1996). "From Unemployment to Self-Employment. Labour Market Policies for Business Start-up.” In G. Schmidt, J. O’Reilly and K. Schömann (eds.), International Handbook of Labour Market Policy and Evaluation. Cheltenham: Edward Elgar, 489-519.

Niefert, M. and M. Tchouvakhina. (2006). "Gründungen aus der Arbeitslosigkeit - Besondere Merkmale und Unterschiede zu anderen Gründungen.” Mittelstands- und Strukturpolitik 35, 109-123.

Parker, S. C. (2004). “The Economics of Self-employment and Entrepreneurship.” New York: Cambridge University Press. 
Pfeiffer, F. and F. Reize. (2000). "Business Start-ups by the Unemployed - an Econometric Analysis based on Firm Data.” Labour Economics 7, 629-663.

Portes, A. and M. Zhou (1996). "Self-employment and the Earnings of Immigrants." American Sociological Review 61, 219-230.

Reize, F. (2000). “Leaving Unemployment for Self-employment. A Discrete Duration Analysis of Determinants and Stability of Self-employment among Former Unemployed.” ZEW Discussion Paper No. 00-26.

Reuber, A. R. and E. Fischer. (1999). "Understanding the Consequences of Founders' Experience.” Journal of Small Business Management, Vol. 37, 30-45.

Reynolds, P. D., Bosma, N., Autio, E., Hunt, S, Bono, N. de, Servais, I., Lopez-Garcia, P. and N. Chin. (2005). "Global Entrepreneurship Monitor: Data Collection Design and Implementation 1998-2003.” Small Business Economics 24, 205-231.

Reynolds, P. D.,Camp, S. M., Bygrave, W. D., Autio, E. and M. Hay. (2002). “Global Entrepreneurship Monitor 2001 Executive Report.” Babson College, London Business School.

Riley, J. (1979) “Testing the Educational Screening Hypothesis.” Journal of Political Economy 87, S227-S252.

Robinson, P. and E. Sexton. (1994). “The Effect of Education and Experience on SelfEmployment Success.” Journal of Business Venturing 9, 141-156.

Sandner, P., Block, J. H. and A. Lutz. (2007). "Determinanten des Erfolgs staatlich geförderter Existenzgründungen - eine empirische Untersuchung.” SSRN Working Paper. 
Sapienza, H. and C. Grimm. (1997). "Founder Characteristics, Start-up Process, and Strategy/structure Variables as Predictors of Shortline Railroad Performance.” Entrepreneurship Theory and Practice 21, 5-24.

Schiller, B. R. and P. E. Crewson. (1997). "Entrepreneurial Origins: A Longitudinal Inquiry." Economic Inquiry 35, 523-532.

Schultz, T. W. (1961). "Investment in Human Capital." American Economic Review 51, $1-17$.

Schwarz, E. J., Ehrmann, T. and R. J. Breitenecker. (2005). "Erfolgsdeterminanten junger Unternehmen in Österreich: eine empirische Untersuchung zum Beschäftigungswachstum.” Zeitschrift für Betriebswirtschaft 75, 1077-1098.

Shane, S. (2000). "Prior Knowledge and the Discovery of Entrepreneurial Opportunities." Organization Science 11, 448-469.

Siow, A. (1984). “Occupational Choice under Uncertainty.” Econometrica 52, 631-645.

Sternberg, R., Brixy, U. and J. F. Schlapfner. (2006).“Global Entrepreneurship Monitor. Länderbericht Deutschland 2005.” Universität Hannover and IAB.

Sternberg, R., Brixy, U. and C. Hundt. (2007). “Global Entrepreneurship Monitor. Länderbericht Deutschland 2006.” Universität Hannover and IAB.

Van Praag, C. M. (2003). "Business Survival and Success of Young Small Business Owners." Small Business Economics 21, 1-17.

Von Hagen, J., Strauch, R. R. and G. B. Wolff. (2002). "East Germany: Transition with Unification: Experiments and Experiences." University of Bonn, Centre for European Integration 
Wagner, J. (2003). “Testing Lazear's Jack of-all-trades View of Entrepreneurship with German Micro Data.” Applied Economics Letters 10, 687-689.

Wagner, J. (2004). "What a difference a Y makes-Female and Male Entrepreneurs in Germany." Small Business Economics 28, 1-21.

Wagner, J. (2005). "Nascent Necessity and Opportunity Entrepreneurs in Germany: Evidence from the Regional Entrepreneurship Monitor (REM)." University of Lüneburg Working Paper Series in Economics No. 10.

Wießner, F. (2000). "Erfolgsfaktoren von Existenzgründungen aus der Arbeitslosigkeit - Eine multivariate Betrachtung vormals arbeitsloser Existenzgründer, die vom Arbeitsamt mit dem Überbrückungsgeld (§ 57 SGB III) gefördert wurden.” Mitteilungen aus der Arbeitsmarkt und Berufsforschung 33, 518-532.

Wooldridge, J. M. (2002a). “Introductory Econometrics: A Modern Approach.” South Western College Publishing, $2^{\text {nd }}$ ed., pp. 530-534.

Wooldridge, J. M. (2002b). "Econometric Analysis of Cross Section and Panel Data." Cambridge (MA) and London (UK): The MIT Press, pp. 477-478. 